Scientia Agricola

http://dx.doi.org/10.1590/0103-9016-2013-0274

\title{
Reclamation status of a degraded pasture based on soil health indicators
}

\author{
Cristiane Alcantara dos Santos ${ }^{1}$, Cristina Célia Krawulski², Daniel Bini ${ }^{3}$, Tadeu Goulart Filho ${ }^{1}$, Adriana Knob ${ }^{3}$, Cristiane Conti \\ Medina $^{4}$, Galdino Andrade Filho ${ }^{1}$, Marco Antonio Nogueira ${ }^{*}$
}

\author{
${ }^{1}$ State University of Londrina, UEL - Dept. of Microbiology, \\ C.P. 10.011 - 86057-970 - Londrina, PR - Brazil. \\ 2Parana Institute of Technical Assistance and Rural Extension, \\ EMATER. Unidade Municipal de Londrina. Rod. Celso Garcia \\ Cid, km 375 - 86044-290 - Londrina, PR - Brazil. \\ ${ }^{3}$ The Midwest State University, UNICENTRO - Dept. of \\ Biological Sciences, R. Simeão Camargo Varela de Sá, 03 - \\ 85040-080 - Guarapuava, PR - Brazil. \\ ${ }^{4}$ State University of Londrina - Dept. of Agronomy. \\ ${ }^{5}$ Embrapa Soybean - Lab. of Soil Biotechnology, C.P. $231-$ \\ 86001-970 - Londrina, PR - Brazil. \\ *Corresponding Author <marco.nogueira@embrapa.br>
}

Edited by: Thomas Jot Smyth

Received August 24, 2013

Accepted August 31, 2014

\begin{abstract}
Pasture degradation is a concern, especially in susceptible sandy soils for which strategies to recover them must be developed. Microbiological and biochemical soil health indicators are useful in the guindace of soil management practices and sustainable soil use. We assessed the success of three Panicum maximum Jacq. cultivars in the reclamation of a pasture in a sandy Typic Acrudox in the northwest of the state of Paraná, Brazil, based on soil health indicators. On a formerly degraded pasture with Urochloa brizantha (Hochst. ex A. Rich.) R.D. Webster, a trial with three P. maximum (cv. Massai, Tanzânia, or Mombaça) was conducted. Lime and phosphate were applied at set-up, and mineral $\mathrm{N}$ and $\mathrm{K}$ as topdressing. A remnant of degraded pasture adjacent to the trial was used as control. Twenty-three chemical, physical, microbiological and biochemical attributes were assessed for the 0-10 cm topsoil. The procedures for reclamation improved most of the indicators of soil health in relation to the degraded pasture, such as soil $\mathrm{P}$, mineral $\mathrm{N}$, microbial biomass $\mathrm{C}$, ammonification rate, dehydrogenase activity and acid phosphatase. $\mathrm{CO}_{2}$ evolution decreased, whereas microbial biomass $\mathrm{C}$ increased in the pasture under reclamation, resulting in a lower metabolic quotient $\left(\mathrm{qCO}_{2}\right)$ that points to a decrease in metabolic stress of the microbial community. The reclamation of the pasture with P. maximum, especially cv. Mombaça, were evidenced by improvements in the microbiological and biochemical soil health indicators, showing a recovery of processes related to $\mathrm{C}, \mathrm{N}$ and $\mathrm{P}$ cycling in the soil.

Keywords: microbial biomass, bio-indicators, soil enzymes, soil quality, reclamation of pastures
\end{abstract}

\section{Introduction}

Inappropriate management of pastures caused by overgrazing and the neglected or insufficient reposition of nutrients via fertilizers and liming are regarded as causes for the decline of pastures (Corazza et al., 2003; De Bona and Monteiro, 2010; Dias-Filho et al., 2001). The low vigor and yield of forages in degraded pastures impair animal growth and performance, culminating in physical, chemical, and microbiological degradation of the soil (Boddey et al., 2004; Oliveira et al., 2004).

Soil health is intrinsically associated with its capacity to support the biological yield in an ecosystem, maintain the environmental balance, and plant, animal and human health (Doran et al., 1996). Consequently, soil health also reflects the potential of the soil for its usage, plant productivity, and sustainability of an agroecosystem (Sposito and Zabel, 2003).

A sustainable agricultural or natural ecosystem depends on the flow of nutrients along the trophic levels, which are mediated, in the main, by microorganisms that transform the soil organic matter (Cardoso et al., 2013). The soil microbial community is considered essential in any ecosystem. It acts on decomposition and synthesis of soil organic matter, nutrient cycling and changes the physical and chemical properties of the soil, and affects soil fertility and sustainability. On the other hand, the soil microbial community is dynamic and is easily affected by land use and management, leading to changes in its structure and function, resulting in a new equilibrium (Bini et al., 2013; Cardoso et al., 2013).
The decrease in the inputs and quality of organic residues in the soil also affect its organic carbon content and microbial activity, leading to changes in the biodiversity and balance of dynamic processes like $\mathrm{C}$ and nutrient cycling (Oliveira et al., 2004; Potthast et al., 2010). In a degraded pasture, biological processes in the soil are also impaired, and initiatives for reclamation must also recover or improve the soil biological processes. Therefore, microorganisms and microbial processes associated with $\mathrm{C}, \mathrm{N}$, and $\mathrm{P}$ cycling are of particular interest to the maintenance of soil health, especially in tropical environments (Dias-Filho et al., 2001; Cardoso et al., 2013).

We assessed the effect of three P. maximum cultivars used in the reclamation of a degraded pasture, evaluating a number of indicators of soil health, in a sandy soil in the northwest state of Paraná, south Brazil, as compared to an adjacent degraded pasture.

\section{Materials and Methods}

\section{Field site description}

The study was carried out in Jaguapitã, in the northwest of the state of Paraná, southern Brazil $\left(23^{\circ} 02^{\prime} 52^{\prime \prime} \mathrm{S} ; 51^{\circ} 33^{\prime} 32^{\prime \prime} \mathrm{W}\right)$ on a 12-ha module of milk production under pasture, belonging to family smallholders. The area has an average altitude of $557 \mathrm{~m}$, a slightly undulating landscape, with less than a $6 \%$ slope, and a Cfa climate according to Köppen. The soil was classified as Typic Acrudox (Soil Survey, USDA), with sandy texture (859 $\mathrm{g} \mathrm{kg}^{-1}$ sand, $129 \mathrm{~g} \mathrm{~kg}^{-1}$ clay), 
bulk density $1.62 \mathrm{~g} \mathrm{~cm}^{3}$, originating from "Caiuá" sandstone, with low natural fertility.

In 1995, a pasture with Urochloa brizantha (Hochst. ex A. Rich.) R.D. Webster was sown, and no fertilizers or limestone were added subsequently after. In 1999, the pasture had low forage production, which, together with soil erosion, led to low capacity for supporting cattle. From 2000 to 2004, part of the degraded pasture was converted to low-input cropping of maize (Zea mays L.) or sorghum (Sorghum bicolor L. Moench) each year in the summer for production of silage, and black oat (Avena sativa L.), and in the winter for continuous cattle grazing. The cropping system was conventional, with one plowing $(0-20 \mathrm{~cm})$ and at least four harrowings $(0-10 \mathrm{~cm})$ annually. During this period, the crops received liming and fertilizers but less than their needs, resulting in soil-degrading, non-profitable activity.

\section{Treatments, experimental design and sampling}

In Sep 2004, as part of a governmental program to improve smallholder inputs and their quality of life (Krawulski et al., 2011), a pilot trial on pasture reclamation was initiated. The soil received dolomitic limestone sufficient to reach $60 \%$ of base saturation at $0-20 \mathrm{~cm}$, incorporated by plowing over an area of 9 ha. In Dec 2004, three treatments with Panicum maximum Jacq. (cv. Massai, Tanzânia, or Mombaça) were applied in two paddocks of 1.5 ha each, with two replicates, in a completely randomized block design.

Before sowing, $70 \mathrm{~kg} \mathrm{ha}^{-1}$ of $\mathrm{P}$ were applied at a rate of $1: 1$ of single superphosphate and Arad reactive natural phosphate and incorporated into the soil to a depth of $0-10 \mathrm{~cm}$ depth, by harrowing. After that, seeds were sown at a rate of $10.9 \mathrm{~kg} \mathrm{ha}^{-1}$ for Massai, $6.4 \mathrm{~kg}$ ha $^{-1}$ for Mombaça, and $8.3 \mathrm{~kg} \mathrm{ha}^{-1}$ for Tanzânia, which represented $18 \%, 34 \%$, and $24 \%$ of the crop value of seeds, repectively. Plots were fertilized with $200 \mathrm{~kg} \mathrm{ha}^{-1}$ of $\mathrm{N}\left[\left(\mathrm{NH}_{4}\right)_{2} \mathrm{SO}_{4}\right]$ and $50 \mathrm{~kg} \mathrm{ha}^{-1}$ of $\mathrm{K}(\mathrm{KCl})$ divided into four applications (Jan, Mar, Oct and Dec 2005), applied as topdressing.

Each 1.5-ha paddock was divided into five parts separated by electrified fences in Mar 2005, with 65 cows grazing each part for three days in a rotational grazing system. As control, a 3-ha remnant degraded pasture with $U$. brizantha close to the trial plots (less than $200 \mathrm{~m}$ away), and employed for secondary continuous pasturing, was used for comparison. The annual forage dry biomass production was estimated (Cecato et al., 2000) at $12.7 \mathrm{t} \mathrm{ha}^{-1}$ for Mombaça, $11.0 \mathrm{t} \mathrm{ha}^{-1}$ for Tanzânia, $8.7 \mathrm{t} \mathrm{ha}^{-1}$ for Massai and $0.9 \mathrm{t} \mathrm{ha}^{-1}$ for degraded pasture with $U$. brizantha.

Soil sampling was carried out in Sep 2005 in the $0-10 \mathrm{~cm}$ layer within a $15 \times 5 \mathrm{~m}$ grid, each plot with 15 single samples, which were pooled and sieved (4 $\mathrm{mm}$ ) to form a composite sample. To increase the representativeness of the sampling, two transects were randomly established on the plots of the first block, and three were established on the plots of the second block, forming five replications for each treatment, in an unbalanced randomized block design. In the degraded control pasture, two transects close to the first block, and three close to the second block were randomly established and sampled as above.

The trial and the degraded pasture were neighbors, sharing the same soil type, slope and microclimate, so that the expected differences would be attributed to the process employed for pasture reclamation and $P$. maximum cultivars. In the lab, soil samples were oven-dried, air-dried, or stored at $5{ }^{\circ} \mathrm{C}$, depending on the analysis to be carried out. Root segments retained on the sieve were stored in a preservative solution 125 $\mathrm{mL}$ glacial acetic acid, $500 \mathrm{~mL}$ ethanol, $120 \mathrm{~mL}$ formamide, $1,000 \mathrm{~mL}$ distilled $\mathrm{H}_{2} \mathrm{O}$ ) for further assessment of mycorrhizal colonization.

Concomitant with the soil sampling, diagnostic leaves, i.e., the two newly expanded leaves (Batista and Monteiro, 2007) were sampled for $\mathrm{N}$ and $\mathrm{P}$ analysis after drying $\left(65^{\circ} \mathrm{C}\right)$ to constant weight and grinding in a Willey mill.

\section{Soil physical and chemical attributes, and plant analysis}

Soil moisture at the sampling date was determined gravimetrically after drying at $105^{\circ} \mathrm{C}$ to express all results on a dry basis. Oven-dried samples were also used for determination of the water-dispersed clay (WDC) (Embrapa, 1997). Air-dried soil samples were used for assessments of $\mathrm{pH}$ in $0.01 \mathrm{~mol} \mathrm{~L}^{-1} \mathrm{CaCl}_{2}$, and $\mathrm{P}$ after extraction with Mehlich I solution (IAPAR, 1992). Total $\mathrm{N}$ was determined in sulfuric extracts (Bremner and Mulvaney, 1982), whereas organic C was determined by $\mathrm{C}$ oxidation with dichromate (Yeomans and Bremner, 1988). The mineral $\mathrm{N}$ (ammonium + nitrate) was quantified in $2 \mathrm{~mol} \mathrm{~L}^{-1} \mathrm{KCl}$ extracts by steam distillation (Keeney and Nelson, 1982) in field-moist samples stored at $5{ }^{\circ} \mathrm{C}$. Total $\mathrm{N}$ in leaves was determined in sulfuric digests (Bremner and Mulvaney, 1982), whereas $\mathrm{P}$ was determined in nitric-perchloric digests (Sarruge and Haag, 1974).

\section{Microbiological and biochemical attributes}

Microbiological activity was based on the $\mathrm{CO}_{2}$ evolution incubation method using $0.25 \mathrm{~mol} \mathrm{~L}^{-1} \mathrm{NaOH}$ as a trap for 21 days (Alef, 1995). Microbial biomass $\mathrm{C}$ and $\mathrm{N}$ were determined by the fumigation-extraction method (Vance et al., 1987). Microbial C was quantified in $0.5 \mathrm{~mol} \mathrm{~L}^{-1} \mathrm{~K}_{2} \mathrm{SO}_{4}$ extracts by oxidation with dichromate (Anderson and Ingram, 1993), while microbial $\mathrm{N}$ was determined in the same extracts after digestion with sulfuric acid (Brookes et al., 1985).

For calculations, biomass $\mathrm{C}$ considered a fator $\mathrm{K}_{\mathrm{C}}$ $=0.33$ (Vance et al., 1987), whereas biomass $\mathrm{N}$ considered $\mathrm{K}_{\mathrm{N}}=0.68$ (Brookes et al., 1985). The metabolic quotient $\left(q \mathrm{CO}_{2}\right)$ considered the amount of $\mathrm{C}-\mathrm{CO}_{2}$ 
released per unit of microbial biomass C over time (Anderson and Domsch, 1993). The ammonification rate was based on the concentration of ammoniacal-N before and after incubation and was expressed as $\mu \mathrm{g}$ $\mathrm{N}-\mathrm{NH}_{4}{ }^{+} \mathrm{g}^{-1} \mathrm{~d}^{-1}$, whereas the nitrification rate was based on the percentage of conversion of $\mathrm{N}^{-\mathrm{NH}_{4}}{ }^{+}$, added as $\left(\mathrm{NH}_{4}\right)_{2} \mathrm{SO}_{4}$, into $\mathrm{N}-\mathrm{NO}_{3}{ }^{-}$after incubation for $21 \mathrm{~d}$ at 28 ${ }^{\circ} \mathrm{C}$ (Schuster and Schröder, 1990), considering the concentrations of $\mathrm{N}-\mathrm{NH}_{4}{ }^{+}$and $\mathrm{N}-\mathrm{NO}_{3}{ }^{-}$before and after the incubation time. Ammonifying microorganisms were estimated by most probable number (MPN) in serial dilutions of soil samples in quintuplicate vials (Sarathchandra, 1978).

Preserved roots were assessed for mycorrhizal colonization after clarification and staining with tripan blue under optical microscope at $100 \times$ magnification (Brundrett et al., 1996).

Biochemical analyses included dehydrogenase (Casida et al., 1964), and acid and alkaline phosphatase (Tabatabai and Bremner, 1969) activities. In addition, hot water soluble carbohydrates (HWC) were also assessed (Ball et al., 1996). All these procedures were performed with field-moist soil samples stored at $5{ }^{\circ} \mathrm{C}$ for up to seven days after sampling.

\section{Statistical Analysis}

The dataset was analyzed for homogeneity of variances and normal distribution. Considering that the composite samples taken in each transect were independent, the main exigencies for applying ANOVA were fulfilled, and thus each composite sample was considered an independent replicate (Hairston, 1989). Thus, the dataset was submitted to ANOVA with application of the $\mathrm{F}$ test, considering a randomized unbalanced block design. Means were compared by Tukey's test ( $p \leq 0.05$ ) using SISVAR software, version 4.6 (Build 62). In addition, a multivariate analysis was performed with principal component analysis (PCA) using the CANOCO 4.5 software for Windows to have a general view of the behavior of the attributes assessed under each treatment.

\section{Results and Discussion}

\section{Physical and chemical attributes}

In general, soil water content at sampling time was low because the rainy season in the region was still not well established, in addition to the low water holding capacity of the sandy soil (Table 1). Similar results were found in a sandy soil in samplings taken during the dry season in the Cerrado region (Frazão et al., 2010). The control soil (degraded pasture) had slightly higher water content levels as compared to the soil with Massai grass,

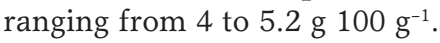

Total organic $\mathrm{C}$ did not differ between the pastures under reclamation and the degraded pasture, but somewhat higher water content was found in the soil of the degraded pasture. However, the contents of soil organic $\mathrm{C}$ were too low, as a result of the pasture degradation process (Noble et al., 2008) and the soil mixing by plowing and harrowing in the attempt to establish annual crops for silage during the five years before pasture reclamation.

The control soil also showed higher $\mathrm{pH}$ than the pasture under reclamation. Despite the fact that the pasture under reclamation had received liming, it also received mineral $\mathrm{N}$ as ammonium sulfate, which contributed to decreases in soil $\mathrm{pH}$ as a result of nitrification that releases $\mathrm{H}^{+}$into the soil, in addition to net excretion of $\mathrm{H}^{+}$to maintain the electro-neutrality during the uptake of ammonium and other cations (Noble et al., 2008). Sandy soils have low CEC and consequently low buffering capacity. Thus, the use of acidifying $\mathrm{N}$-fertilizes, especially ammonium sulfate, leads to rapid acidification.

Higher plant biomass production in the plots that received liming and fertilizers resulted in more absorption and exportation of bases from the soil, contributing to acidification. On the other hand, the degraded pasture with $U$. brizantha, as a consequence of no fertilization with mineral-N, low capacity for biomass production and less exportation of bases, showed higher $\mathrm{pH}$ than the plots under reclamation. As a consequence, liming must

Table 1 - Physical and chemical attributes of a sandy soil (Typic Acrudox), and N and P concentrations in leaves of forages in pastures under reclamation or degraded.

\begin{tabular}{|c|c|c|c|c|}
\hline \multirow{3}{*}{ Attribute } & \multicolumn{4}{|c|}{ Treatments (forages) } \\
\hline & \multicolumn{3}{|c|}{ Reclamation with Panicum maximum } & \multirow{2}{*}{$\begin{array}{c}\text { Degraded } \\
\text { Urochloa brizantha }\end{array}$} \\
\hline & Mombaça & Tanzânia & Massai & \\
\hline Moisture (g $100 \mathrm{~g}^{-1}$ ) & $4.2 \mathrm{ab}$ & $5.0 \mathrm{ab}$ & $4.0 \mathrm{~b}$ & $5.2 \mathrm{a}$ \\
\hline $\mathrm{pH}\left(0.01 \mathrm{~mol} \mathrm{~L}^{-1} \mathrm{CaCl}_{2}\right)$ & $5.0 \mathrm{~b}$ & $5.1 \mathrm{~b}$ & $5.1 \mathrm{~b}$ & $6.2 \mathrm{a}$ \\
\hline Soil P (mg kg-1) & $6.6 \mathrm{a}$ & $7.2 \mathrm{a}$ & $7.8 \mathrm{a}$ & $2.2 \mathrm{~b}$ \\
\hline Plant P ( $\mathrm{g} \mathrm{kg}^{-1}$ ) & $3.4 a b$ & $3.1 \mathrm{~b}$ & $3.8 \mathrm{a}$ & $3.5 \mathrm{a}$ \\
\hline Mineral $\mathrm{N}^{1}\left(\mathrm{mg} \mathrm{kg}^{-1}\right)$ & $3.8 \mathrm{a}$ & $3.8 \mathrm{a}$ & $3.3 \mathrm{ab}$ & $2.9 \mathrm{~b}$ \\
\hline Plant N (g kg-1) & $15.1 \mathrm{a}$ & $15.8 \mathrm{a}$ & $14.5 \mathrm{a}$ & $13.5 \mathrm{a}$ \\
\hline Soil total $\mathrm{N}\left(\mathrm{g} \mathrm{kg}^{-1}\right)$ & $0.42 \mathrm{a}$ & $0.45 a$ & $0.41 \mathrm{a}$ & $0.38 \mathrm{a}$ \\
\hline$W D C^{2}\left(\mathrm{~g} \mathrm{~kg}^{-1}\right)$ & $18 \mathrm{a}$ & $20 \mathrm{a}$ & $23 a$ & 14 a \\
\hline Soil organic $\mathrm{C}\left(\mathrm{g} \mathrm{kg}^{-1}\right)$ & $2.6 \mathrm{a}$ & $3.2 \mathrm{a}$ & $3.5 \mathrm{a}$ & $4.4 \mathrm{a}$ \\
\hline
\end{tabular}

Means with same letters do not differ (Tukey, $p<0.05$ ); ${ }^{1}$ Mineral $\mathrm{N}=$ ammonium + nitrate; ${ }^{2} \mathrm{WDC}=$ Water dispersed clay. 
be more frequent in the case of more intensive pastures, especially in sandy soils with low buffering capacity, and should aim to reduce the effects of excessive acidity on pasture that is intensively managed .

The addition of P-fertilizer increased the soil available $\mathrm{P}$ in the plots under reclamation as compared to degraded pasture (Table 1). However, half the applied $\mathrm{P}$ was in the form of natural phosphate, resulting in an overestimation when using the Mehlich I acidic extractor. In an exploratory sampling the year before, using the same extractor (data not shown), available $\mathrm{P}$ was 2.2 and $9.4 \mathrm{mg} \mathrm{kg}^{-1}$ in both the degraded and the reclamation pastures, respectively. In the low-productivity degraded pasture, the values remained the same, while in the pasture under reclamation there was a decrease in available $\mathrm{P}$, as a consequence of more intense exportation due to more abundant growth of the forage that sustained more intense grazing, and, consequently, more exportation of nutrients.

$\mathrm{P}$ concentration in the plants did not follow the concentration in the soil (Table 1). Similar results were found elsewhere, i.e., correlation between available $\mathrm{P}$ and $\mathrm{P}$ concentrations in plants was significant only when soil sampling was performed under the tussocks of $U$. brizantha (Corazza et al., 2003). Among the forages, the lowest $\mathrm{P}$ concentration was found in Tanzânia, differing from Massai and the control, $U$. brizantha. This effect was probably a consequence of a dilution effect, where forages that produced more biomass had lower concentrations of $\mathrm{P}$. In addition, inter-varietal and interspecies differences in $\mathrm{P}$ concentrations must also be taken into account. The mycorrhizal colonization is generally an important biological attribute associated with plant $\mathrm{P}$ nutrition, but did not show differences between the treatments (Table 2).

The mineral $\mathrm{N}$ in the soil under degraded pasture was lower in relation to the pasture recovered with Mombaça and Tanzânia. A residual effect of fertilization with $\mathrm{N}$ is implausible, because mineral $\mathrm{N}$ is very dynamic in the soil, especially sandy soils like the featured in this trial. However, an indirect effect could be attributed to the greater forage biomass produced in the sites under reclamation, in addition to greater root biomass (data not shown), resulting in more organic material in the soil being mineralized and releasing mineral $\mathrm{N}$, which is in agreement with the higher ammonification rate in the recovered pastures (Table 2).

$\mathrm{N}$ concentration in plants and soil total $\mathrm{N}$ did not differ between treatments (Table 1). Although $\mathrm{N}$ concentrations in $U$. brizantha were above $13 \mathrm{~g} \mathrm{~kg}^{-1}$, considered optimal for this grass (Häussler et al., 2006), a maximum dry matter yield was found only at $22.8 \mathrm{~g} \mathrm{~kg}^{-1}$ of $\mathrm{N}$ (De Bona and Monteiro, 2010), far above the concentrations found for all forages in this study, which ranged from $13.5 \mathrm{~g} \mathrm{~kg}^{-1}$ to $15.8 \mathrm{~g} \mathrm{~kg}^{-1}$. However, in the degraded pasture, not only $\mathrm{N}$ might have been limiting, but also several other nutrients, resulting in biomass production that was too low.

WDC and total C did not change with treatments, although soil total $\mathrm{C}$ had been very low in all treatments, notably in the pasture under reclamation, as discussed above (Table 1).

\section{Microbiological and biochemical attributes}

Most of the soil microbiological attributes in the pasture under reclamation differed from the control soil (Table 2), as they showed more sensitivity to making evident the effects of soil use and management based on ANOVA. Similar results were found in the Brazilian Cerrado, where attributes relating to soil fertility and nutrient concentrations in tissues were not sensitive indicators of pasture degradation, but microbial biomass $\mathrm{C}$ was (Oliveira et al., 2004).

Microbial biomass $\mathrm{C}$ was relatively high compared to a previous study on a sandy soil in the Cerrado region in Central Brazil (Frazão et al., 2010). Probably, in our study the climate with more well distributed rainfall in the winter preceding the sampling in the spring was more favorable to the plants, which are sources of $\mathrm{C}$ for the microbial community. Soils lacking, or under scarce vegetation, have generally low amounts of microbial biomass when compared to soils under abundant vegetation (Frazão et al., 2010; Bini et al., 2013), reinforcing the role of plants by helping with the maintenance of microbial communities in soil, which is favored by adequate soil moisture (Frazão et al., 2010).

The higher amount of microbial biomass $\mathrm{C}$ in the soil with Mombaça, followed by Massai, Tanzânia,

Table 2 - Microbiological attributes in a sandy soil (Typic Acrudox), in pastures under reclamation or degraded.

\begin{tabular}{|c|c|c|c|c|}
\hline \multirow{3}{*}{ Attribute } & \multicolumn{4}{|c|}{ Treatments (forages) } \\
\hline & \multicolumn{3}{|c|}{ Reclamation with Panicum maximum } & \multirow{2}{*}{$\begin{array}{c}\text { Degraded } \\
\text { Urochloa brizantha }\end{array}$} \\
\hline & Mombaça & Tanzânia & Massai & \\
\hline Ammonifying (log MPN g-1) & $5.7 \mathrm{ab}$ & $5.7 b$ & $5.3 \mathrm{~b}$ & $6.3 a$ \\
\hline Mycorrhizal colonization (\%) & 35 a & $32 \mathrm{a}$ & $34 \mathrm{a}$ & $22 \mathrm{a}$ \\
\hline Respiration ( $\mu \mathrm{g} \mathrm{CO} \mathrm{g}^{-1} \mathrm{~d}^{-1}$ ) & $42.8 b$ & $41.3 b$ & $35.8 b$ & $57.6 \mathrm{a}$ \\
\hline Microbial biomass $\mathrm{C}$ ( $\mu \mathrm{g} \mathrm{C} \mathrm{g}^{-1}$ ) & 790 a & $595 \mathrm{ab}$ & $654 \mathrm{ab}$ & $490 \mathrm{~b}$ \\
\hline Ammonification rate ( $\mu \mathrm{g} \mathrm{N} \mathrm{g}^{-1} \mathrm{~d}^{-1}$ ) & $0.46 \mathrm{a}$ & $0.39 \mathrm{a}$ & $0.35 \mathrm{a}$ & $0.06 \mathrm{~b}$ \\
\hline Nitrification rate (\%) & $32 \mathrm{ab}$ & $29 \mathrm{~b}$ & $35 a$ & $35 a$ \\
\hline
\end{tabular}

Means with same letters do not differ (Tukey, $p<0.05$ ). 
and the degraded pasture with $U$. brizantha, with the lowest, indicated a best condition for the soil microbial community with the improvement of the pasture. The recovered pasture had more inputs of organic $C_{\text {, includ- }}$ ing rhizodeposition and maintenance of soil moisture, which are favorable to the soil microbial community (Frazão et al., 2010; Lacerda et al., 2013). The microbial biomass contributes to improved soil fertility because the cells constitute a living reservoir of $\mathrm{C}$ and nutrients, avoiding their fixation in the mineral fraction, like $\mathrm{P}$, or from leaching through the soil profile, like nitrate (Cardoso et al., 2013; Fagotti et al., 2012). Once stored in the microbial biomass, nutrients can be easily released to plants after death and mineralization of microbial cells. Thus, pasture management systems that favor the soil microbial biomass contribute to the sustainability of this agroecosystem, especially because they activate the biogeochemical cycles (Dias-Filho et al., 2001).

The microbial activity measured as $\mathrm{CO}_{2}$ evolution was the highest in the soil with degraded pasture, despite the lowest microbial biomass. The $\mathrm{CO}_{2}$ evolution alone is not sufficient to explain the effects of soil use and management on microbial activity, where higher respiration rates do not necessarily mean good conditions for microbial community (Frazão et al., 2010). As a result, the highest $q \mathrm{CO}_{2}$ in the degraded pasture, as compared to the pastures recovered with Mombaça and Massai forages, suggests stress-inducing conditions for the microbial community. Higher $q \mathrm{CO}_{2}$ means less metabolically efficient microbial activity, because this community requires more intense respiration to keep the same unit of microbial biomass as compared to a non-stressed microbial community (Anderson and Domsch, 1993; Lacerda et al., 2013), since microorganisms have to invest more energy for self-maintenance under conditions of stress. Thus, $q \mathrm{CO}_{2}$ can be used as a sensitive indicator of the soil microbial community stress. Consequently, the pasture reclaimed with Mombaça and Massai emerged as a less stress-inducing environment to the soil microbial community as compared to degraded pasture.

Despite the greater occurrence of ammonifying microorganisms in the degraded pasture soil, there was no correspondence with the ammonification rate, which was the lowest in this soil (Table 2). Although the soil has a microbial community with the potential to mineralize $\mathrm{N}$, the sources and the quantity of organic $\mathrm{N}$ are less subjected to mineralization (Fagotti et al., 2012). The lower amount of plant biomass produced in the degraded pasture $\left(0.9 \mathrm{t} \mathrm{ha}^{-1}\right)$ resulted in less rhizodeposition and input of organic material, and thus reduced the inputs and stocks of mineralizable $\mathrm{N}$ in the soil. Consequently, the lowest ammonification rate was found in the degraded pasture as compared to the recovered sites, independent of the forage used. The nitrification rate, however, decreased in the pasture under reclamation with Tanzânia grass, as compared to the degraded pasture.

Higher nitrification rates indicate more probability of $\mathrm{N}$ losses by leaching or denitrification (Schuster and Schröder, 1990), and is favored at a higher pH (Fagotti et al., 2012) as observed in the degraded pasture. In addition to the lower potential for $\mathrm{N}$ supply from organic $\mathrm{N}$ reservoirs, the soil of the degraded pasture has greater potential for converting ammonium into nitrate, which is easily lost through leaching or denitrification (Cardoso et al., 2013). Thus, the degraded pasture has negative aspects regarding the sustainability of the production system, because a greater supply of mineral $\mathrm{N}$ (and other nutrients) as fertilizers would be needed, in addition to the increase in risk to the environment.

Pasture reclamation also affected soil biochemical attributes, regardless of the forage employed (Table 3). The dehydrogenase activity, as an indicator of microbial activity and oxidative processes, was the lowest in the degraded pasture, which corroborates the corresponding lower microbial biomass C. More intense oxidative processes also contribute to increases in oxidation of organic $\mathrm{C}$, which might lead to decreases in soil organic $\mathrm{C}$ in the long term (Potthast et al., 2012), if the inputs of organic $\mathrm{C}$ are in negative balance. As an indicator of microbial activity, dehydrogenase activity shows that the pasture reclamation also contributed to stimulating the microbial activity as a result of more plant biomass as well as the nutrients in the soil, notably $\mathrm{P}$.

The recent history of soil mixing in the preceding annual crops in the pasture under reclamation may still be having an effect on the oxidative processes as indicated by the dehydrogenase activity. The acid phosphatase had a similar trend, with increased activity in the pasture under reclamation. Consequently, the soil capacity for P supply was enhanced, notably from organic sources (Lacerda et al., 2013). Conversely, the alkaline phosphatase had the inverse behavior, as a consequence of a higher $\mathrm{pH}$ in the degraded pasture soil. The acid phosphatase has microbial, vegetal and

Table 3 - Biochemical attributes in a sandy soil (Typic Acrudox), in pastures under reclamation or degraded.

\begin{tabular}{lrcrr}
\hline & \multicolumn{3}{c}{ Treatments (forages) } \\
\cline { 2 - 4 } Attributes & Mombaça & Reclamation with Panicum maximum & Degraded \\
\cline { 2 - 4 } & $13.2 \mathrm{a}$ & $13.0 \mathrm{a}$ & $10.3 \mathrm{a}$ & Urochloa brizantha \\
\hline Dehydrogenase $^{1}\left(\mu \mathrm{g} \mathrm{TF} \mathrm{g}^{-1} \mathrm{~d}^{-1}\right)$ & $180.4 \mathrm{a}$ & $172.9 \mathrm{a}$ & $158.0 \mathrm{a}$ & $103.7 \mathrm{~b}$ \\
Acid phosphatase $^{2}\left(\mu \mathrm{g} \mathrm{PNF} \mathrm{g}^{-1} \mathrm{~h}^{-1}\right)$ & $90.7 \mathrm{~b}$ & $78.3 \mathrm{~b}$ & $87.3 \mathrm{~b}$ & $120.7 \mathrm{a}$ \\
Alk. phosphatase $^{2}\left(\mu \mathrm{g} \mathrm{PNF} \mathrm{g}^{-1} \mathrm{~h}^{-1}\right)$ & $121.2 \mathrm{a}$ & $115.2 \mathrm{a}$ & $117.2 \mathrm{a}$ & $151.0 \mathrm{a}$ \\
Carbohydrates $^{3}\left(\mu \mathrm{g} \mathrm{RS} \mathrm{g}^{-1}\right)$ & &
\end{tabular}

Means with same letters do not differ (Tukey, $p<0.05$ ); ${ }^{1}$ TTF = Trifenil Tetrazolium Formazan; ${ }^{2} \mathrm{PNF}=\mathrm{p}$-nitrophenol; ${ }^{3 \mathrm{RS}}=$ Reducing sugars. 
animal origin (Vance et al., 2003), whereas the alkaline phosphatase is exclusively of microbial origin and is stimulated by higher $\mathrm{pH}$ values (Rojo et al., 1990). Thus, the $\mathrm{P}$ restriction in the degraded pasture did not stimulate the acid phosphatase, but only the alkaline phosphatase, which was also favored by the higher $\mathrm{pH}$ of the degraded pasture.

The hot water soluble carbohydrates, which are the labile fraction of soil organic matter, did not change with treatments, although they followed the same trend of soil organic C (Table 3).

\section{Global data analysis by principal component analy- sis (PCA)}

PCA based on chemical, physical, and C-associated soil attributes showed a clear distribution of the treatments along axis 1, which explained about $95 \%$ of the variability (Figure 1). The degraded pasture with $U$. brizantha was highly associated with soil $\mathrm{pH}$, moisture, respiration, hot water soluble carbohydrates, and $q \mathrm{CO}_{2}$. The treatment with Mombaça grass was highly associated with microbial biomass $\mathrm{C}$. In addition, the treatments with Massai and Tanzânia showed more similarities between each other and were associated with higher dehydrogenase activity and WDC, in an intermediate fashion between Mombaça and $U$. brizantha.

Greater association between microbial biomass C and Mombaça is in agreement with the greater biomass this forage had produced $\left(12.7 \mathrm{t} \mathrm{ha}^{-1}\right)$. As a consequence, more residues, including roots and rhizodeposition that

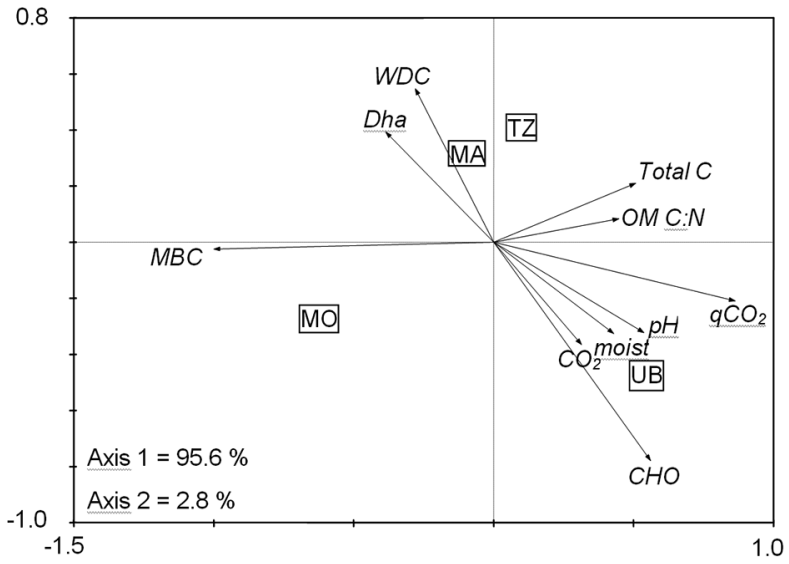

Figure 1 - Principal component analysis (PCA) based on soil chemical and physical attributes, and microbiological attributes associated to $\mathrm{C}$ cycling. Degraded pasture with Urochloa brizantha (UB), recovered pasture with Panicum maximum cv. Mombaça (MO), Tanzânia (TZ), and Massai (MA). CHO = Hot water soluble carbohydrates; $\mathrm{CO}_{2}=$ Soil respiration; Dha $=$ Activity of dehydrogenase; $\mathrm{MBC}=$ Microbial biomass $\mathrm{C}$; moist = Soil moisture; $O M C: N=C$ to $\mathrm{N}$ ratio of the soil organic matter; $\mathrm{pH}=$ Soil $\mathrm{pH} ; \mathrm{qCO}_{2}=$ Metabolic quotient; Total $\mathrm{C}=$ Total organic $\mathrm{C}$ in soil; $W D C=$ Water-dispersed clay. returned to the soil might have stimulated the microbial community (Potthast et al., 2010). However, the fertilization and liming may also have stimulated the microbial community due to the very low soil fertility level, contrary to Potthast et al. (2012), who found that soil fertility was not limiting to the soil microbial community. Thus, the use of forages with better performance, like Mombaça grass, associated with liming and fertilization, results in stimuli to microbial processes in soil, which can result in a more effective $\mathrm{C}$ and nutrient cycling, and thus improve the sustainability of the pasture under reclamation as compared to the degraded pasture (DiasFilho et al., 2001).

The second PCA based on attributes associated with $\mathrm{N}$ and $\mathrm{P}$ cycling also permitted a distinction between treatments (Figure 2) to be made. Axis 1 explained almost $94 \%$ of the variability, where the degraded pasture was associated mainly with the nitrification rate and ammonifying microorganisms, and, to a lesser extent, to alkaline phosphatase and microbial biomass $\mathrm{N}$. On the other hand, the recovered pasture showed a closer relationship with mineral $\mathrm{N}$, acid phosphatase, ammonification rate, available $\mathrm{P}$, mycorrhizal colonization, total $\mathrm{N}$ in the soil, and $\mathrm{N}$ concentration in plants. While the degraded pasture was associated with the nitrification rate, indicating potential for $\mathrm{N}$ losses from the soil, the pastures under reclamation had more association with attributes related to a more active cycling of $\mathrm{N}$ and $\mathrm{P}$, and thus contributed to the sustainability of the pasture under reclamation.

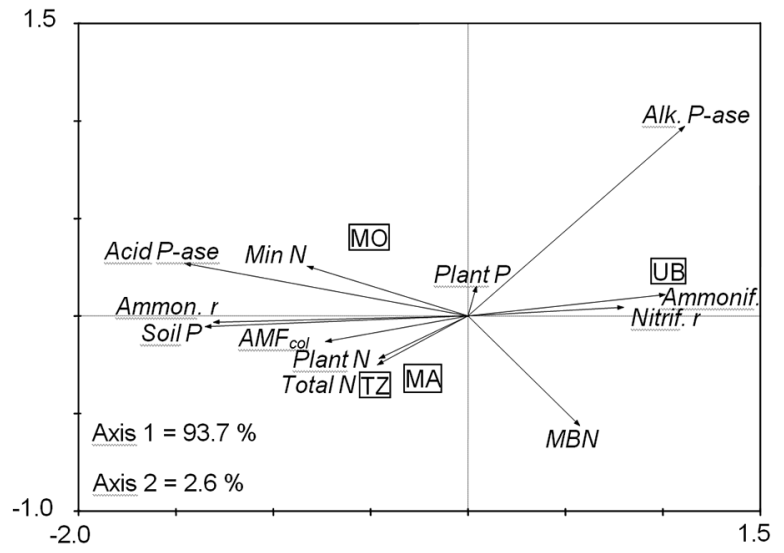

Figure 2 - Principal component analysis (PCA) based on soil attributes associated with $\mathrm{N}$ and $\mathrm{P}$ cycling. Degraded pasture with Urochloa brizantha (UB), recovered pasture with Panicum maximum cv. Mombaça (MO), Tanzânia (TZ), and Massai (MA). Acid P-ase = Acid phosphatase; Alk. P-ase: Alkaline phosphatase; $A M F_{c o l}=$ Arbuscular mycorrhizal root colonization; Ammon. $r=$ Ammonification rate; Ammonif. = ammonifying microorganisms; MBN = Microbial biomass Nitogen; Min $N=$ Mineral Nitrogen in soil; Nitrif. $r=$ Nitrification rate; Plant $N=$ Nitrogen concentration in plants; Plant $P=$ Phosphorus concentration in plants; Soil $P=$ Soil available $P$; Total $N=$ Soil total $N$. 
The recovery of degraded pastures also entails recovery of the soil microbial attributes associated with a better capacity of soil for $\mathrm{C}$ and nutrient cycling, mainly $\mathrm{N}$, with a consequent increase in the sustainability of the production system as compared with the degraded pasture. The improvement of soil health of degraded pastures and their reintegration into the productive system is necessary for land-use that is sustainable in this susceptible environment which is based on a sandy soil, naturally low in fertility.

\section{Acknowledgments}

To Brazilian National Council for Scientific and Technological Development (CNPq) and Coordination for the Improvement of Higher Level Personnel (CAPES) for providing undergraduate, master, doctoral and research productivity scholarships to the authors.

\section{References}

Alef, K. 1995. Soil respiration. p. 214-219. In: Alef, K.; Nannipieri, P., eds. Methods in applied soil microbiology and biochemistry. Academic Press, London, UK.

Anderson, T.H.; Domsch, K.H. 1993. The metabolic quotient from $\mathrm{CO}_{2}\left(q \mathrm{CO}_{2}\right)$ as a specific activity parameter to assess the effects of environmental conditions, such as $\mathrm{pH}$, on the microbial biomass of forest soils. Soil Biology and Biochemistry 25: 393-395.

Anderson, J.M.; Ingram, J.S.I. 1993. Tropical Soil Biology and Fertility: a Handbook of Methods. CAB International, Wallingford, UK.

Ball, B.C.; Cheshire, M.V.; Robertson, E.A.G.; Hunter, E.A. 1996. Carbohydrate composition in relation to structural stability, compactability and plasticity of two soils in a long-term experiment. Soil and Tillage Research 39: 1647-1653.

Batista, K.; Monteiro, F.A. 2007. Nitrogen and sulphur in Marandu grass: relationship between supply and concentration in leaf tissues. Scientia Agricola 64: 44-51.

Bini, D.; Santos, C.A.; Carmo, K.B.; Kishino, N.; Andrade, G.; Zangaro, W.; Nogueira, M.A. 2013. Effects of land use on soil organic carbon and microbial processes associated with soil health in southern Brazil. European Journal of Soil Biology 55: 117-123.

Boddey, R.M.; Macedo, R.; Tarré, R.M.; Ferreira, E.; Oliveira, O.C.; Rezende, C.P.; Cantarutti, R.B.; Pereira, J.M.; Alves, B.J.R.; Urquiaga, S. 2004. Nitrogen cycling in Brachiaria pastures: the key to understanding the process of pasture decline. Agriculture, Ecosystems and Environment 103: 389403.

Bremner, J.M.; Mulvaney, C.S. 1982. Nitrogen-total. p. 595-624. In: Page, A.L.; Miller, R.H.; Keeney, D.R., eds. Methods of soil analysis. Part 2. Chemical and microbiological properties. American Society of Agronomy, Madison, WI, USA.

Brookes, P.C.; Landman, A.; Pruden, G.; Jenkinson, D.S. 1985. Chloroform fumigation and the release of soil nitrogen: a rapid direct extraction method to measure microbial biomass nitrogen in soil. Soil Biology and Biochemistry 17: 837-842.
Brundrett, M.; Beergher, N.; Dell, B.; Groove, T.; Malajczuk, N. 1996. Working with Mycorrhizas in Forestry and Agriculture. ACIAR, Canberra, Australia.

Cardoso, E.J.B.N.; Vasconcellos, R.L.F.; Bini, D.; Miyauchi, M.Y.H.; Santos, C.A.; Alves, P.R.L.; Paula, A.M.; Nakatani, A.S.; Pereira, J.M.; Nogueira, M.A. 2013. Soil health: looking for suitable indicators. What should be considered to assess the effects of use and management on soil health? Scientia Agricola 70: 280-295.

Casida, L.E.; Klein, D.A.; Santoro, T. 1964. Soil dehydrogenase activity. Soil Science 98: 371-376.

Cecato, U.; Machado, A.O.; Martins, E.N.; Pereira, L.A.F.; Barbosa, M.A.A.F.; Santos, G.T. 2000. Evaluation of production and any physiological characteristics of genotypes of Panicum maximum Jacq. under two cutting heights. Revista Brasileira de Zootecnia 29: 660-668.

Corazza, E.J.; Brossard, M.; Muraoka, T.; Coelho Filho, M.A. 2003. Spatial variability of soil phosphorus of a low productivity Brachiaria brizantha pasture. Scientia Agricola 60: 559-564.

De Bona, F.D.; Monteiro, F.A. 2010. Marandu palisade grass growth under nitrogen and sulphur for replacing signal grass in degraded tropical pasture. Scientia Agricola 67: 570-578.

Dias-Filho, M.B.; Davidson, E.A.; Carvalho, C.J.R. 2001. Linking biogeochemical cycles to cattle pasture management and sustainability in the Amazon basin. p. 84-105. In: McClain, M.E.; Victoria, R.L.; Richey, J.E., eds. The biogeochemistry of the Amazon basin. Oxford University Press, New York, NY, USA.

Doran, J.W.; Sarrantonio, M.; Liebig, M. 1996. Soil health and sustainability. p. 1-54. In: Sparks, D.L., ed. Advances in agronomy. Academic Press, San Diego, CA, USA.

Empresa Brasileira de Pesquisa Agropecuária [EMBRAPA]. 1997. Handbook of Methods of Soil Analysis = Manual de Métodos de Análise de Solo. Serviço Nacional de Levantamento e Classificação de Solos, Rio de Janeiro, RJ, Brazil.

Fagotti, D.S.L.; Miyauchi, M.Y.H.; Oliveira, A.G.; Santinoni, I.A.; Eberhardt, D.N.; Nimtz, A.; Ribeiro, R.A.; Paula, A.M.; Queiroz, C.A.S.; Andrade, G.; Zangaro, W.; Nogueira, M.A. 2012. Gradients in N-cycling attributes along forestry and agricultural land-use systems are indicative of soil capacity for N supply. Soil Use and Management 28: 292-298.

Frazão, L.A.; Piccolo, M.C.; Feigl, B.J.; Cerri, C.C.; Cerri, C.E.P. 2010. Inorganic nitrogen, microbial biomass and microbial activity of a sandy Brazilian Cerrado soil under different land uses. Agriculture, Ecosystems and Environment 135: 161-167.

Hairston, N.G. 1989. Ecological Experiments: Purpose, Design and Execution. Cambridge University Press, Cambridge, UK.

Häussler, K.; Rao, I.M.; Schultze-Kraft, R.; Marschner, H. 2006. Shoot and root growth of two tropical grasses, Brachiaria ruziziensis and $B$. dictyoneura, as influenced by aluminium toxicity and phosphorus deficiency in a sandy loam Oxisol of the eastern plains of Colombia. Tropical Grasslands 40: 213221.

Instituto Agronômico do Paraná [IAPAR]. 1992. Handbook of Soil Chemical Analysis and Quality Control = Manual de Análise Química do Solo e Controle de Qualidade. IAPAR, Londrina, PR, Brazil. (Circular Técnica, 76) (in Portuguese). 
Keeney, D.R.; Nelson, D.W. 1982. Nitrogen inorganic forms. p. 643-698. In: Page, A.L.; Miller, R.H.; Keeney, D.R., eds. Methods of soil analysis. Part 2. Chemical and microbiological properties. SSSA-ASA, Madison, MI, USA.

Krawulski, C.C.; Medina, C.C.; Almeida, B.L.; Souza, N.A.; Iácono, G.M.P. 2011. Municipal development in Jaguapitã (Paraná State, Brazil): from theoretical conception to first results. Geografia 20: 67-84.

Lacerda, K.A.P.; Cordeiro, M.A.S.; Verginassi, A.; Salgado, F.H.M.; Paulino, H.B.; Carneiro, M.A.C. 2013. Organic carbon, biomass and microbial activity in an Oxisol under different management systems. Revista de Ciências Agrárias 56: 249254.

Noble, A.D.; Suzuki, S.; Soda, W.; Ruaysoongnern, S.; Berthelsen, S. 2008. Soil acidification and carbon storage in fertilized pastures of northeast Thailand. Geoderma 144: 248-255.

Oliveira, O.C.; Oliveira, I.P.; Alves, B.J.R.; Urquiaga, S.; Boddey, R.M. 2004. Chemical and biological indicators of decline/ degradation of Brachiaria pastures in the Brazilian Cerrado. Agriculture, Ecosystems and Environment 103: 289-300.

Potthast, K.; Hamer, U.; Makeschin F. 2010. Impact of litter quality on mineralization processes in managed and abandoned pasture soils in southern Ecuador. Soil Biology and Biochemistry 42: 56-64.

Potthast, K.; Hamer, U.; Makeschin F. 2012. In an Ecuadorian pasture soil the growth of Setaria sphacelata, but not of soil microorganisms, is co-limited by $\mathrm{N}$ and P. Applied Soil Ecology 62: 103-114.
Rojo, M.J.; Carcedo, S.G.; Mateos, M.P. 1990. Distribution and characterization of phosphatase and organic phosphorus in soil fractions. Soil Biology and Biochemistry 22: 169-174.

Sarathchandra, S.V. 1978. Nitrification activities and the changes in the population of nitrifying bacteria in soil perfused with two different H-ion concentrations. Plant and Soil 50: 99-111.

Sarruge, J.R.; Haag, H.P. 1974. Chemical Analysis in Plants = Análises Químicas em Plantas. ESALQ-USP, Piracicaba, SP, Brazil (in Portuguese).

Schuster, E.; Schröder, D. 1990. Side effects of sequentially-applied pesticides on target soil microorganisms: field experiments. Soil Biology and Biochemistry 22: 367-373.

Sposito, G.; Zabel, A. 2003. The assessment of soil quality. Geoderma 114: 143-144.

Tabatabai, M.A.; Bremner, J.M. 1969. Use of p-nitrofenol phosphate for assay of soil phosphatase activity. Soil Biology and Biochemistry 1: 301-307.

Vance, C.P.; Uhde-Stone, C.; Allan, D.L. 2003. Phosphorus acquisition and use: critical adaptations by plants for securing a nonrenewable resource. New Phytologist 157: 423-447.

Vance, E.D.; Brookes, P.C.; Jenkinson, D.S. 1987. An extraction method for measuring soil microbial biomass C. Soil Biology and Biochemistry 19: 703-707.

Yeomans, J.C.; Bremner, J.M. 1988. A rapid and precise method for routine determination of organic carbon in soil. Communications in Soil Science and Plant Analysis 19: 14671476. 